\title{
RISK ANALYSIS IN THE REALIZATION OF BUILDINGS IN REVITALIZED AREAS
}

\begin{abstract}
A. SOBOTKA ${ }^{1}$, A. RADZIEJOWSKA ${ }^{2}$
Construction work on buildings covered by the revitalization program of historic urban development represents a special type of construction project in which, in the execution phase, difficult technical situations and other risk sources are being encountered. An important source of risk is the necessity to preserve a part of the historic substance, which results, among others, from the recommendations of the conservator, legal regulations or from the vision of the architect/investor. The risk is also associated with difficulties and complications in construction works resulting from the location of these objects in dense urban development. The aim of the article is to identify risk factors and reactions of contractors, i.e. applied risk management methods and techniques, based on the example of a complex of buildings constructed in the historic district of Krakow. The elimination of sources of risk, especially of a technical nature, requires the construction management to be highly skilled and experienced, to carefully prepare the construction work and to design additional solutions to ensure safety at work. The experience gained may serve as a basis for risk analysis and identification during the implementation of projects involving the use of an existing building and historic substance in areas subject to revitalization programs.
\end{abstract}

Keywords: revitalization, preservation of the historic substance, sources and risk factors, risk management, execution of a construction project

\section{INTRODUCTION}

Cracow is one of the cities in which post-industrial built-up areas are revitalized on a large scale. In Poland and around the world, revitalization of built-up areas combines historic buildings, their

\footnotetext{
${ }^{1}$ Prof., DSc., PhD., Eng., AGH University of Science and Technology in Cracow, Department of Geomechanics, Civil Engineering and Geotechnics, Av. Mickiewicza 30, 30-059 Cracow, Poland, e-mail: sobotka@agh.edu.pl

${ }^{2}$ PhD., Eng., AGH University of Science and Technology in Cracow, Department of Geomechanics, Civil Engineering and Geotechnics, Av. Mickiewicza 30, 30-059 Cracow, Poland, e-mail: aradziej@agh.edu.pl
} 
fragments and even equipment with modern architecture and the function of the designed objects ([1]; [2]; [3]; [4]). Examples of such investments can be found in the photographs on the Fig. 1. The construction of such complexes constituting a symbiosis between the new and the old is difficult due to legal (especially concerning the protection of monuments), economic and technical reasons. They are characterized by additional, specific sources and risk factors, not only during their implementation but also during their operation (use) [5]. There are many publications on risk identification and assessment methods in the implementation of construction projects. Most of them are of a general nature, without distinguishing the types of investments carried out (e.g. [6]; [7]; [8]; [9]). The results of research on risk factors presented in the publications generally relate to the construction of new facilities, although attempts are made to analyze and assess the risk in the performance of construction works during the revitalisation including construction, post-industrial and historic buildings [10]; [11].
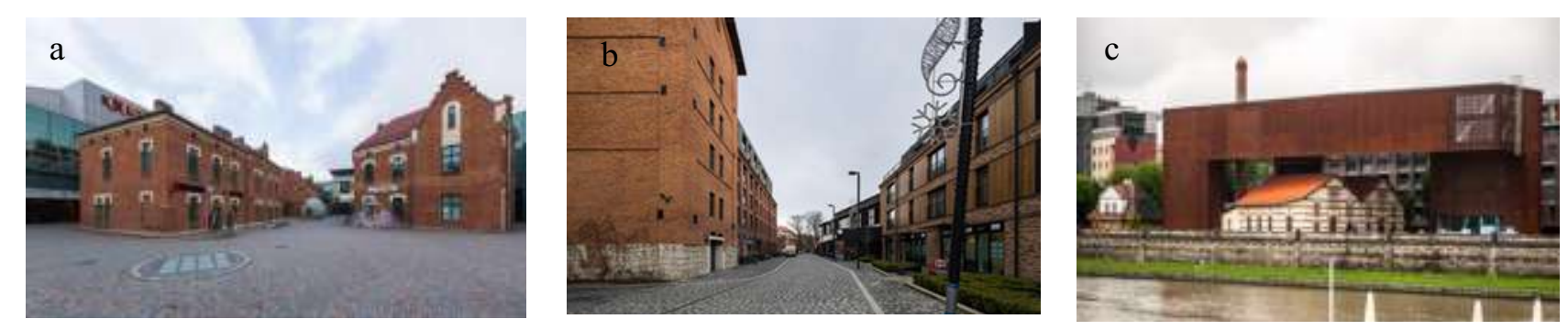

Fig. 1 a) Shopping mall in the former City Slaughterhouse; b) New and historic restored buildings of Lubicz Brewery performing residential and service functions; c) Cricoteka - T. Kantor Art Documentation Centre with buildings and chimney of the old Podgórze Power Plant; Source: [12]

Construction works on buildings included in the revitalisation program are a special type of construction project in which, in particular in the execution phase, there are many difficult technical situations which constitute a source of risk. For these reasons, as well as due to special legal conditions - especially concerning historic buildings and works connected with the preparation of renovation works (until their commencement), they require great care and knowledge of regulations, as well as their good design and planning. Due to the growing scope of construction projects for various purposes in the areas covered by revitalisation programs, the knowledge based on experience is needed in order to identify sources and risk factors, which is necessary for the successful completion of a construction project.

In the article, on the example of observation of the implementation of the housing complex in the area of the former power plant construction in the historical district of Krakow - Kazimierz, the results of the analysis and identification of sources and risk factors of this undertaking were 
presented. They can be the basis for risk assessment in such projects and use in risk management at every stage of the investment cycle. The article is based on the analysis of technical documentation and observation of the progress of works during construction and the experience of the managerial staff of the construction.

\section{IDENTIFICATION OF RISK SOURCES OF EXEMPLARY INVESTMENT}

\subsection{DESCRIPTION OF THE CONSTRUCTION INVESTMENT}

An exemplary investment is the construction of an apartment complex on the area including the buildings of the former municipal power plant (administration building, machine hall, boiler room). Built (and extended) at St. Wawrzyńca Street, in the historic district of Kazimierz, the power plant, from 1905 until the 1960s, supplied almost half of the city with energy. In the following years, the importance of the power plant declined, its operations stopped and for almost 30 years the property had been empty (Fig. 2).
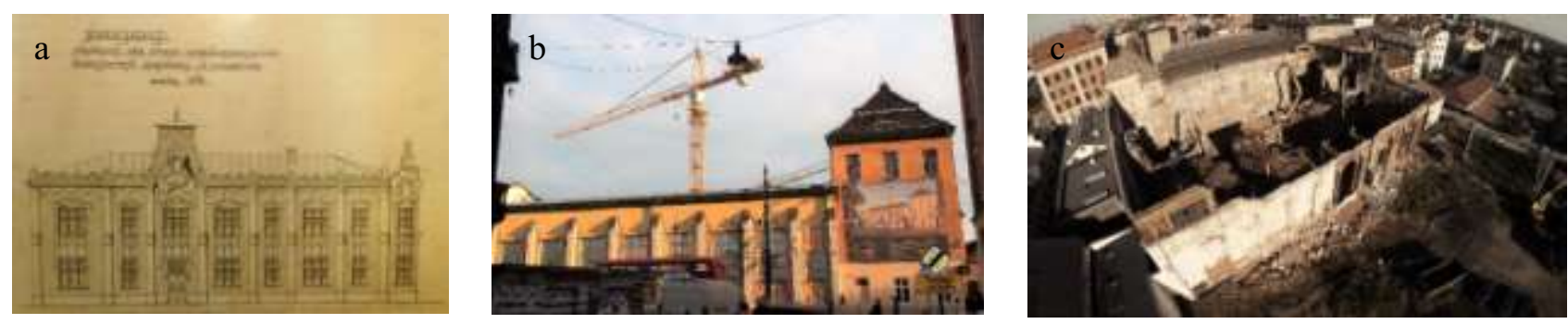

Fig. 2 a) view of the elevation of the Municipal Power Plant in Kraków, years 1906-1908; source: State Archive; b) front wall of power plant before renovation, view from Wawrzyniec Street, 21.09.2015, own archive, c) bird's eye view of the property in 2015 source: http://tekton.krakow.pl/w19-krakow/

The property falling into ruin was purchased from the city by a Haven Sp. z o.o. for residential development. At present, the new construction project is mainly a residential project in a diversified form, i.e. apartments, studio flats and lofts. The ground floors of the buildings are intended for commercial and service activities. Garages were designed under the whole complex, obtaining ZIKIT's consent to connect the entrance and exit from the underground car park to the existing public road.. Pro-ecological solutions in the form of solar panels and charging stations for electric cars located in the underground garage were also applied.

Due to its location, the building has been protected by the conservator, whose indications were used in the architectural design of the complex. These are: 
- preservation of the originality of existing buildings from 1914 and the legibility of new blocks,

- new function of buildings while maintaining current standards and regulations,

- maintenance and display of historic technical devices,

- correspondence of modern building materials with historical elements.

Construction (without demolition works) was carried out in the general contracting system. Meeting the above mentioned recommendations, from the point of view of design and execution, posed great technical and technological-organizational challenges. To this should be added executive and logistic difficulties due to the lack of the construction site (free space is only a courtyard in the middle of a building plot built on all sides). It has to be acknowledged that some construction problems resulting from the needs of the work were taken into account in the preparation and design phase, but most of them were sources of risk faced by the contractor.

\subsection{SOURCES AND RISK FACTORS DURING THE EXECUTION OF THE PROJECT}

During the execution of the investment, it was necessary to apply technology and organization of construction works enforced by the conditions of execution, construction and logistics, including a limited, or even total lack of construction site. These conditions generate additional sources of risk. Some of the risk factors were foreseen at the design stage and steps were taken to minimise their effects. However, in this type of investments, most of the sources of risk are difficult to predict and occur only at the stage of execution of construction works. The sources of these risks result mainly from two types of conditions:

1. difficulties resulting from the location of the object(s) in the area covered by the revitalisation program and, therefore, the need to preserve elements of the historic substance in this area,

2. limited construction site resulting from the location of the investment in dense urban development.

Ad.1. Such difficulties should be envisaged at the stage of investment preparation (e.g. settlement of ownership problems and permission to purchase a plot of land) as well as at the design stage.

In the analyzed example, the buildings of the former power plant consisted of two parts: the industrial one, which consisted of the boiler room B3 and the turbine plant B2 and the administrative building (switchgear and switchgear) B1 (Fig. 3). Pursuant to the Revitalization Plan (PLR), the B1 building, in sufficiently good condition, was the only one to have undergone only 
minor changes, which resulted from the applicable regulations concerning safety of use. On the top floor a historic roof truss was preserved, while in the basement of the building the historic Klein ceilings were cleaned and exhibited. All activities related to its renovation were supervised by the conservator of monuments.

In place of the existing B2 and B3 buildings, new multi-storey buildings with residential and commercial units, in monolithic reinforced concrete technology, with underground garages under the area of the whole complex have been constructed.

The St. Wawrzyńca Quarter Revitalization Program provided for preservation of many historical elements for the investment. It was decided to keep the entire administration building and the adjacent front wall of the former turbine hall B2 from Wawrzyńca Street (Fig. 4). Manual demolition of masonry walls of power plant buildings was carried out, so that after cleaning and preparation of bricks, they could be used again in the new buildings (Fig. 5). Similarly, a part of the power plant's interior furnishings were used, i.e. a part of window and door joinery (Fig. 6), a stone panel, a steel balustrade and a commemorative plaque of the manufacturer [12].

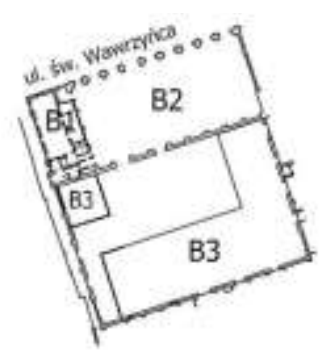

Fig. 3 Ground floor layout of the former power plant complex, [13]

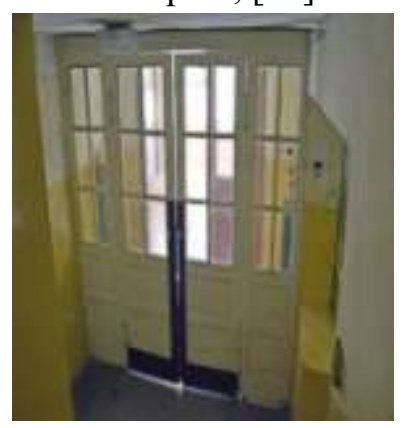

Fig. 6 Paneled wall and double swing doors, Cracow, 2014; source: M. J. Łukacz,

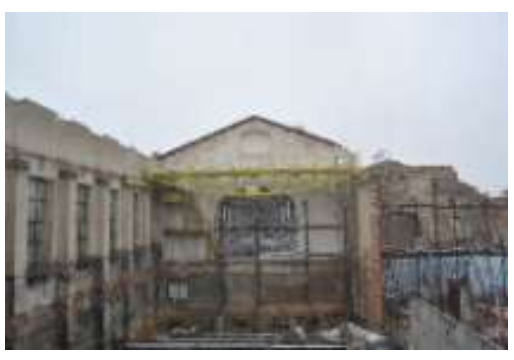

Fig. 4 Old power plant after partial demolition, view of left, 12.10.2015, own archive

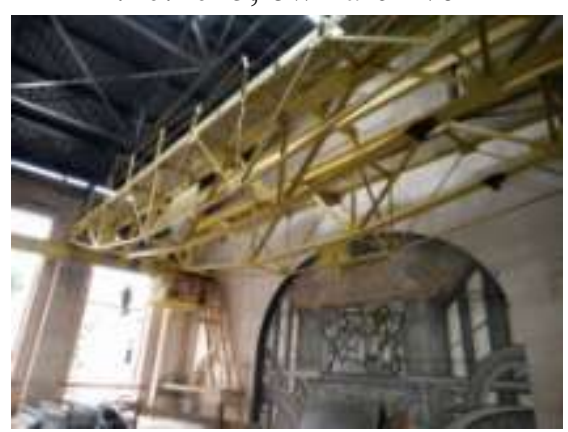

Fig. 7 Historic gantry located in building B2, in the former control room and switchgear before the renovation, 28.06.2016, own archive

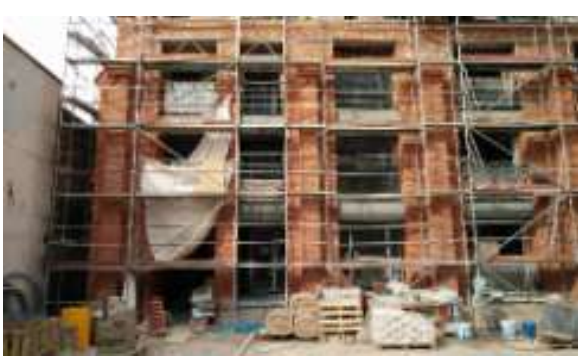

Fig. 5 Built-in historic brick in a newly-built structure 21.03.2017, own archive

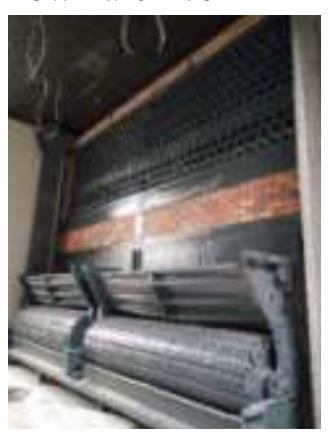

Fig. 8 Two boilers with one drum, steam heater and double grate from Zieleniewski 28.06.2016, own archive 
Industrial equipment of power plants have the character of technical monuments. It was therefore decided to keep several technical equipment in new buildings. This is mainly the gantry in building B2 (Fig. 7), which was one of the most serious sources of risk, and the stoves located in the passageway to the courtyard of the apartment complex (Fig. 8).

Taking into account the conservator's requirements, the technical equipment of the power plant was also renovated of which the most problems were caused by a large gantry located in building B2. The gantry had to be renovated, which was planned by the conservator and designer outside the construction site. Due to its considerable size, weight and lack of consent of the conservator to divide it into smaller parts (for transport), it was decided to leave it for the entire duration of the construction, and to renovate it on site. This decision required the construction of a wall to support the gantry, which was not included in the work schedule. A new wall (Fig. 11) was erected as a substructure, and then the existing wall was demolished, which posed a threat due to its poor technical condition. These works increased the workload and investment costs, in which the General Contractor and the Investor participated.

Due to the location of the investment in the historic development of the Kazimierz district, the monument conservator required that the entire front elevation of the buildings will be preserved. The contractor renovated the façade from St. Wawrzyńca Street, while on the south side part of the walls was demolished, and the recovered brick was cleaned and re-built into the façade of the buildings. In the preliminary cost estimate a partial recovery of the historic brick was envisaged, but due to the impossibility of precise estimation at this stage of planning, it was another source of risk for the time and costs of these works.

Ad.2. Many sources of risk in the project occur due to the location of the construction in dense urban development. In this case, these were the foundations for demolition, difficult hydrogeological conditions, basically lack of space for organizing the construction facilities (only the courtyard and the development area of the complex was available as a construction site), difficult access to the erected structures and the courtyard, as well as inconvenient access to the construction site through narrow passages in the surrounding buildings.

The new complex of buildings was erected on a two-level reinforced foundation slab, below the ground water level. For this reason, the slab was made in the technology of waterproof concrete (so called "white bathtub"). Additionally, before the commencement of the construction of the foundation slab, the subsoil had to be reinforced (included in the detailed design), which was carried out by piling. Problems with the execution of the presented investment appeared already at the beginning of its implementation. At the stage of demolition of fragments of the existing power 
plant construction, it was necessary to reinforce the remaining façade walls of the building complex. The walls left over $15 \mathrm{~m}$. high were secured with a steel support structure (designed at the preparatory stage) (Fig. 10).

The logistics of supplying the construction site with materials and equipment and the logistics of construction works in the existing conditions was extremely complicated. Due to the location of the investment, only a narrow, winding access to a small strip of the storage yard (leased from the neighboring investment) located at the back of the building complex, in the southern part, was possible. Difficult access required proper planning of deliveries of materials with large dimensions and/or long lengths (e.g. reinforcing bars were delivered in sections not exceeding 12 meters). Fig. 9 shows the route of material delivery, which took place from Podgórska Street.

A technological and organizational challenge during the beginning of works was also the location of the crane, the range of which will allow to serve the entire construction site. For this purpose, it was decided to use a 46-metre-high crane, under which a special reinforced foundation in the construction of slab was made (it was taken into account at the design stage). Reinforcement of the foundation slab was done in two directions, crosswise, two levels. Spacers were used between the top and bottom chords to stiffen the slab structure during the concreting process. Due to its size, the foundation slab was divided into smaller plots and made in stages, and additionally the contractor assigned one of the plots for a temporary storage yard.

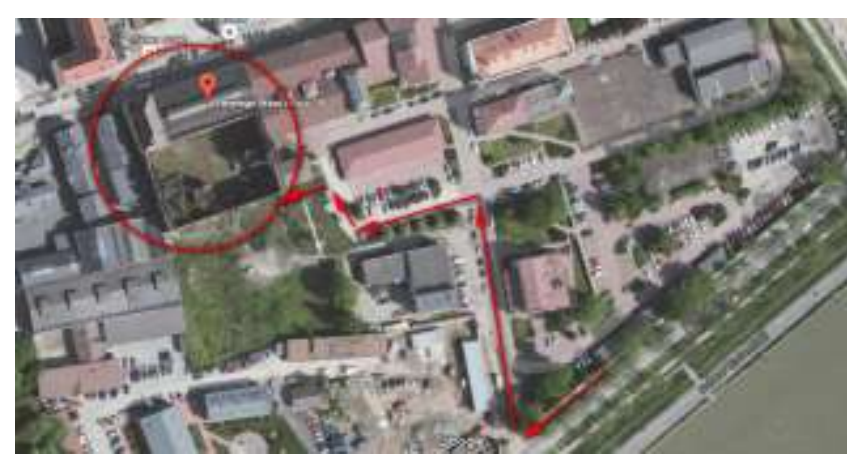

Fig. 9 Location of the investment with marked access for technological transport, may 2014

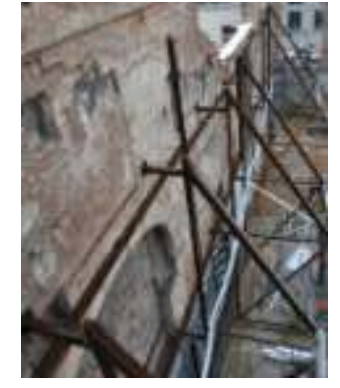

Fig. 10 Protection of walls with steel supporting structure, own archive, 12.10.2015

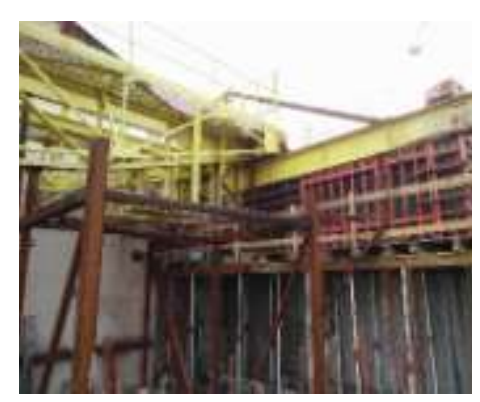

Fig. 11 Construction of a new supporting wall for a historic gantry, own archive, 09.03.2016

The location of landfills, containers, as well as the indication of material and entry points for machines also required difficult decisions. In addition to planning the changing location of storage sites, a technological entrance was designed and built in the future structure of the building on the side of St. Wawrzyńca Street (Fig. 12). The slab above the garages, constituting a temporary 
entrance to the construction site, has been additionally reinforced here to allow entry of concrete mixer truck, pumps and an additional car crane into the courtyard of the future building complex. Moreover, during the implementation of the project (in mid-March 2016), in order to accelerate the concrete works, it was also decided to install a second tower crane (from the west) at the level of the already existing slab above the garages. The decision to rent an additional tower crane for the duration of the reinforced concrete works, as well as the costs of renting it, were taken by the subcontractor. The reason for his actions was originally too slow execution of the works, which could lead to exceeding the deadline and the associated large financial penalties. In order to reduce the impact of this risk, the subcontractor decided to speed up the work by hiring additional working brigades and leasing more formwork, which also required the hiring of an additional crane.

In the second stage of construction (May 2016), the technical corridor was plugged. As the works progressed, material storage sites and social rooms changed their location several time.

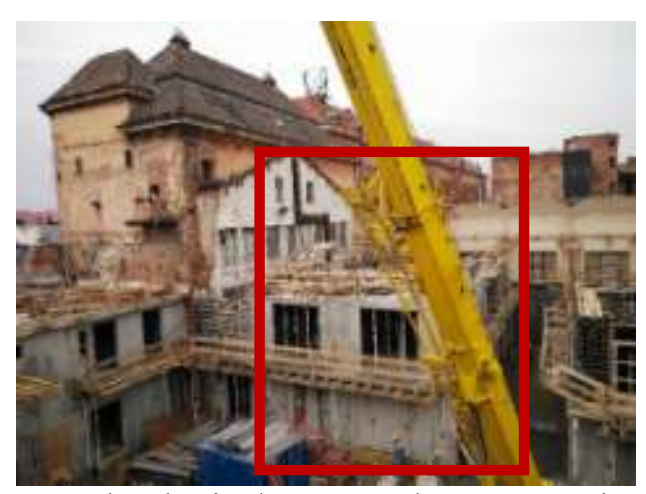

Fig. 12 Technological entry to the construction site, own archive, 03.03.2016

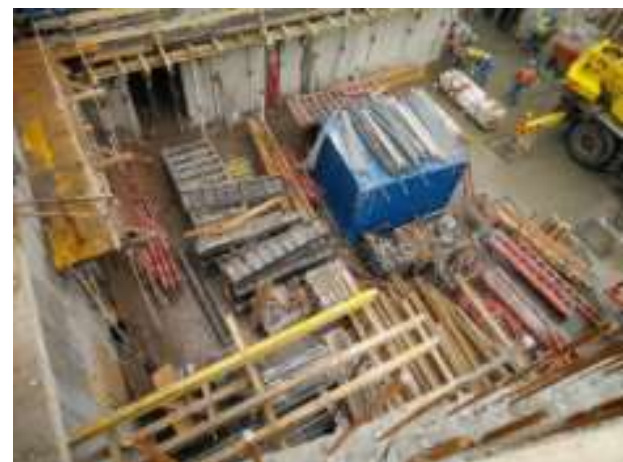

Fig. 13 One of the temporary storage yards, own archive, 03.03.2016

At the finishing stage, building materials stored in the courtyard and on individual building slabs were successively moved from place to place, in order to avoid collisions during the works. At this stage of works the problem also turned out to be the distance over which the mixture should be given to the parts of structures and substrates (distances of more than 40 meters in a straight line). Podwykonawca musiał sprowadzić pompę o podajniku z zasięgiem umożliwiającym wtłoczenie mieszanki do najdalszych fragmentów budynków. The subcontractor had to import a feeder pump with a range that allowed the mixture to be pumped into the farthest parts of the buildings. 


\section{CONSTRUCTION EXPERIENCE AND THEIR ANALYSIS}

The implementation of the Wawrzyńca 19 project was carried out efficiently and in accordance with the planned schedule. It should be acknowledged that certain sources of risk have been foreseen and taken into account in the preparation and design phase of a building complex (e.g. good ground recognition and design of watertight concrete foundations, reinforcement of slabs under cranes and construction machinery), however, most of them were sources of risk faced by the contractor. The reinforced slab at ground level was used to organize work to speed up work, thus reducing the risk of exceeding construction time. Leaving the gantry in the construction and its necessary renovation, although planned for the preparatory phase, was in fact a major technical problem, generating additional costs (which were financed by the investor) and time.

Experiences from the implementation of this investment confirm the need for the participants of the project to cooperate in risk management, the need to better identify sources of risk and to take appropriate steps at the preparation and design stage - which will simplify for the contractor to manage the risk during construction works.

Construction works on the existing buildings covered by the revitalization plan are performed for many reasons, e.g. bad technical condition, necessity to change the way of use (e.g. resulting from the liquidation of industrial plants), not fulfilling the present requirements, etc.. Projects of this type, like others, are covered by legislation. The stages of proceedings in the preparatory phase for obtaining a permit for refurbishment works are similar to the general scheme, however, it should be noted that an additional participant in the administrative proceedings is the Municipal or Provincial

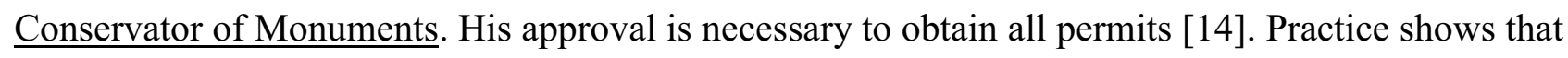
the preparatory phase of an investment project, which precedes the execution of construction works on historic buildings, is usually longer than the other phases of the project [15].

Execution of construction projects in the areas of revitalization is exposed to additional risks, which do not occur in new constructions. Table 1 summarizes the risk factors during typical and historic construction projects, resulting from various conditions affecting the project. It should be noted that they do not exhaust all possible resulting from the individual character of construction production as described in the literature on the subject. 
Table 1. List of risk factors occurring during the execution of projects

\begin{tabular}{|c|c|c|c|}
\hline 1 & 2 & 3 & 4 \\
\hline $\begin{array}{l}\mathrm{N} \\
\mathrm{o}\end{array}$ & $\begin{array}{l}\text { Risk factors occurring during the execution of } \\
\text { typical investments }\end{array}$ & $\begin{array}{l}\mathrm{N} \\
\mathrm{o} .\end{array}$ & $\begin{array}{l}\text { Additional risk factors (apart from those listed in col. 2) } \\
\text { for investments in revitalised or historic areas }\end{array}$ \\
\hline \multicolumn{4}{|c|}{ LEGAL CONDITIONS } \\
\hline 1 & Obtaining appropriate work permits & 1 & $\begin{array}{l}\text { Demolition of the facility or its parts under conservation } \\
\text { protection }\end{array}$ \\
\hline 2 & Lack of precise contractual provisions & 2 & $\begin{array}{l}\text { Required additional designs and permits for the } \\
\text { reinforcement of structural elements for the duration of } \\
\text { the project (e.g. reinforcement of the slab for the } \\
\text { foundation of the crane) }\end{array}$ \\
\hline \multicolumn{4}{|c|}{ ECONOMIC CONDITIONS } \\
\hline 3 & $\begin{array}{l}\text { Inconsistencies/errors in the project } \\
\text { documentation and the resulting calculation } \\
\text { difficulties }\end{array}$ & 3 & $\begin{array}{l}\text { Necessity to plan unusual solutions related to efficient } \\
\text { logistics at the construction site }\end{array}$ \\
\hline 4 & $\begin{array}{l}\text { Necessity to meet the deadline for completion } \\
\text { of works imposed by the Investor }\end{array}$ & 4 & $\begin{array}{l}\text { Additional costs related to the need to switch off the lane } \\
\text { during work }\end{array}$ \\
\hline 5 & Hard-to-reach materials and equipment & 5 & $\begin{array}{l}\text { Costs related to the need to rent an additional yard for } \\
\text { the storage of construction materials }\end{array}$ \\
\hline 6 & $\begin{array}{l}\text { Unknown technology - no cost estimation } \\
\text { possible }\end{array}$ & & $\begin{array}{l}\text { Unforeseen costs related to the necessity of a historical } \\
\text { substance }\end{array}$ \\
\hline 7 & Volatility of prices of materials and services & & \\
\hline \multicolumn{4}{|c|}{ TECHNICAL AND ORGANISATIONAL CONDITIONS } \\
\hline 8 & $\begin{array}{l}\text { Risk of endangering people's lives associated } \\
\text { with working in noisy, dusty, unfavourable } \\
\text { atmospheric conditions, at height }\end{array}$ & 6 & $\begin{array}{l}\text { Difficulties in assessing the technical condition of the } \\
\text { structure (due to bad technical condition and lack of } \\
\text { documentation) }\end{array}$ \\
\hline 9 & $\begin{array}{l}\text { Changes in the way materials are transported } \\
\text { on the construction site }\end{array}$ & 7 & $\begin{array}{l}\text { Changes in the technology of carrying out works during } \\
\text { the execution of the project }\end{array}$ \\
\hline 10 & $\begin{array}{l}\text { Transport and/or location of heavy equipment } \\
\text { to construction site }\end{array}$ & 8 & $\begin{array}{l}\text { Necessity to plan unusual solutions related to efficient } \\
\text { logistics at the construction site }\end{array}$ \\
\hline 11 & $\begin{array}{l}\text { Changes in the method of foundation or the } \\
\text { need to replace the ground }\end{array}$ & & $\begin{array}{l}\text { Technical difficulties resulting from the necessity to } \\
\text { preserve the historic substance indicated by the } \\
\text { conservator }\end{array}$ \\
\hline 12 & Weather conditions, winter period & & \\
\hline
\end{tabular}

However, many of the sources of risk are repeated in subsequent projects, so it is advisable to collect experience, accumulate knowledge, learn and use both for risk management at the operational level, for the individual stage, and for the whole project.

It is worth mentioning that the presented example of the implementation of a project located in the area of the revitalization program, despite the problems encountered, has been very well realized, which is confirmed by winning the first degree award in the competition Construction of the Year 2017 awarded by PZIiTB, GUNB and MIiR. 


\section{SUMMARY AND CONCLUSIONS}

It is not necessary to justify that the issue of risk and risk management in construction projects is important. And that, in particular, possible sources of risk must be anticipated and taken into account, i.e. managed, identified, eliminated, reduced, etc.. Despite the fact that an increasing number of quantitative methods of risk identification and assessment are presented in the literature, especially for the purpose of forecasting the costs and time of the project, there is a lack of their wide implementation. In most cases, the effects of the risk are borne by the contractor and only appropriate knowledge, experience and competence of site managers allows for their minimization. However, it is important to identify the qualitative risk factors, especially in particularly difficult implementation conditions, which occur in projects carried out in revitalized areas, with the requirements of preserving the historic substance.

Each of the existing difficulties is a potential source of risk of time, costs and quality of the object being constructed. The occurrence of such phenomena also requires compromise decisions (in the discussed example it was e.g. covering the costs of additional works related to the preservation of the historic substance - problems with the gantry). Experiences from this example of project implementation in areas under a revitalisation program can be used in the creation of databases for DSS programs for risk management and as a so-called "good practice" example.

\section{Acknowledgment}

The work was carried out as part of statutory research no. 11.11.100.197 in the Department of Geomechanics, Civil Engineering and Geotechnics of Faculty of Mining and Geoengineering, AGH University of Science and Technology in Cracow.

\section{REFERENCES}

[1] A. Sobotka and A. Radziejowska, "Budowa Cricoteki projekt, cz. 1," Builder, vol. luty, 2015.

[2] E. Radziszewska-Zielina, G. Śladowski, and M. Sibielak, "Planning the reconstruction of a historical building by using a fuzzy stochastic network," Autom. Constr., vol. 84, pp. 242-257, Dec. 2017.

[3] C.-S. Chen, Y.-H. Chiu, and L. Tsai, "Evaluating the adaptive reuse of historic buildings through multicriteria decision-making," Habitat Int., vol. 81, pp. 12-23, Nov. 2018.

[4] J. Korytárová, T. Hanák, and P. E. Lukele, "Economic efficiency of brownfield regeneration: Study of South Moravian projects,” Sci. Rev. Eng. Environ. Sci., vol. 26, no. 2, pp. 151-158, 2017.

[5] L. A. Haidar and A. Talib, "Adaptive Reuse in the Traditional Neighbourhood of the Old City Sana'a -Yemen," Procedia - Soc. Behav. Sci., vol. 105, pp. 811-822, Dec. 2013.

[6] A. Dziadosz, "Przegląd wybranych metod wspomagających analizę ryzyka przedsięwzięć budowlanych," Przeglad Bud., vol. R. 81, nr 7-8, pp. 76-80, 2010. 
[7] D. Skorupka, “Zarządzanie ryzykiem w przedsi ęwzięciach budowlanych,” vol. 3, no. 3, 2008.

[8] M. Połoński and K. Pruszyński, “O Ryzyku ( Multidisciplinary Nature of the Knowledge of the Risk ),” pp. 16, 2006.

[9] J. F. Rockart and S. Lecturer, "ICRAM-1: Model for International Construction Risk Assessment,” J. Manag. Eng., vol. 16, no. 1, pp. 59-69, 2000.

[10] A. Sobotka and P. Jasiak, "Uwzględnienie ryzyka w ocenie czasu w ofercie rewitalizacji obiektu zabytkowego," pp. 651-654, 2009.

[11] A. Sobotka and A. Radziejowska, "Budowa Cricoteki wyzwania realizacyjne, cz. 2," Builder, vol. marzec, 2015.

[12] K. Michalak, "Projekt technologii i organizacji budowy wybranego obiektu budowlanego, praca inż."

[13] Mostostal Warszawa S.A, "Rewitalizacja elektrowni w Krakowie. Nowa inwestycja Wawrzyńca 19 muratorplus.pl," 2015. [Online]. Available: https://www.muratorplus.pl/inwestycje/inwestycjekomercyjne/rewitalizacja-elektrowni-w-krakowie-nowa-inwestycja-wawrzynca-19-aa-wdHn-RisK-9kL3.html. [Accessed: 09-Feb-2019].

[14] U. Dz.U. 2015 poz. 1777, “Ustawa z dnia 9 października o rewitalizacji Dz.U. 2015 poz. 1777,” Minist. Wlaściwy ds Budownictwa Lokal. Plan. i Zagospod. Przestrz. oraz Mieszk., pp. 1-23, 2018.

[15] A. Radziejowska and J. Sagan, "Analysis of the preparatory phase of a construction investment in the area covered by revitalization,” Acta Sci. Pol. Ser. Archit., vol. in progres, 2019.

\section{LIST OF FIGURES AND TABLES:}

Fig. 1 a) Shopping mall in the former City Slaughterhouse; b) New and historic restored buildings of Lubicz Brewery performing residential and service functions; c) Cricoteka - T. Kantor Art Documentation Centre with buildings and chimney of the old Podgórze Power Plant; Source: (Michalak, n.d.)

Fig. 2 a) view of the elevation of the Municipal Power Plant in Kraków, years 1906-1908; source: State Archive; b) front wall of power plant before renovation, view from Wawrzyniec Street, 21.09.2015, own archive, c) bird's eye view of the property in 2015 source: http:/tekton.krakow.pl/w19-krakow/

Fig. 3 Ground floor layout of the former power plant complex, (Mostostal Warszawa S.A, 2015)

Fig. 4 Object after partial demolition, view of left fragments of the old power plant, 12.10.2015, own archive Fig. 5 Built-in historic brick in a newly-built structure 21.03.2017, own archive

Fig. 6 Paneled wall and double swing doors, Cracow, 2014; source: M. J. Łukacz,

Fig. 7 Historic gantry with a lifting capacity of $125 \mathrm{kN}$ located in building $\mathrm{B} 2$, in the former control room and switchgear before the renovation, 28.06.2016, own archive

Fig. 8 Two boilers with one drum, steam heater and double grate from Zieleniewski 28.06.2016, own archive

Fig. 9 Location of the investment with marked access for technological transport, may 2014

Fig. 10 Protection of walls with steel supporting structure, own archive, 12.10.2015

Fig. 11 Construction of a new supporting wall for a historic gantry, own archive, 09.03.2016

Fig. 12 Technological entry to the construction site, own archive, 03.03.2016

Fig. 13 One of the temporary storage yards, own archive, 03.03.2016

Table 1. List of risk factors occurring during the execution of projects 


\section{ANALIZA RYZYKA W REALIZACJI BUDYNKÓW NA OBSZARACH OBJĘTYCH REWITALIZACJĄ}

\section{Słowa kluczowe: rewitalizacja, zachowanie substancji zabytkowej, źródła i czynniki ryzyka, zarządzanie ryzykiem, realizacja} przedsięwzięcia budowlanego

\section{Podsumowanie:}

Roboty budowlane na obiektach objętych programem rewitalizacji zabytkowej zabudowy miejskiej stanowią szczególny rodzaj przedsięwzięcia budowlanego, w którym w fazie wykonawstwa, występuje wiele trudnych sytuacji technicznych i innych uwarunkowań stanowiących źródła ryzyka. Istotnym źródłem ryzyka jest konieczność zachowania części substancji zabytkowej, która wynika m.in. z zaleceń konserwatora zabytków, z przepisów prawnych lub z wizji architekta/inwestora. Ryzyko niosą z sobą też utrudnienia i komplikacje w robotach budowlanych wynikające

z lokalizacji tych obiektów w gęstej zabudowie miejskiej. Z tych względów, a także z powodu szczególnych uwarunkowań prawnych - zwłaszcza dotyczących obiektów zabytkowych i prac związanych z przygotowaniem robót remontowych (do momentu ich rozpoczęcia) wymagają one dużej staranności i znajomości przepisów oraz dobrego ich zaprojektowania i zaplanowania. Z uwagi na coraz szerszy zakres realizacji inwestycji budowlanych o różnym przeznaczeniu na terenach objętych programami rewitalizacji jest potrzebna wiedza oparta na doświadczeniach dotycząca identyfikacji źródeł i czynników ryzyka, która konieczna jest do realizacji przedsięwzięcia budowlanego z sukcesem.

W artykule na przykładzie obserwacji realizacji kompleksu mieszkaniowego na terenie zabudowy byłej elektrowni w zabytkowej dzielnicy Krakowa - Kazimierzu przedstawiono wyniki z analizy i identyfikacji źródeł i czynników ryzyka tego przedsięwzięcia.

Prezentowana inwestycja to budowa kompleksu apartamentów na terenie obejmującym zabudowania dawnej elektrowni miejskiej (budynek administracyjny, hala maszyn, kotłownia). Wybudowana (i rozbudowywana) przy ulicy Św. Wawrzyńca, w zabytkowej dzielnicy Kazimierz elektrownia, od 1905 roku, aż do lat sześćdziesiątych zaopatrywała w energię prawie pół miasta, jednak w kolejnych latach jej znaczenie malało, aż do wstrzymania jej działalności w połowie lat 80-tych. Ze względu na lokalizację obiekt został objęty ochroną i wskazaniami konserwatora, które zastosowano w projekcie architektonicznym kompleksu. Były to:

- zachowanie oryginalności istniejących budynków z roku 1914 oraz czytelność nowych brył,

- nowa funkcja budynków przy zachowaniu obowiązujących norm i rozporządzeń,

- konserwacja i wyeksponowanie zabytkowych urządzeń technicznych,

- korespondowanie współczesnych materiałów budowlanych z elementami zabytkowymi.

Podczas realizacji inwestycji wystąpiła konieczność stosowania technologii i organizacji robót budowlanych wymuszonych warunkami realizacyjnymi, konstrukcyjnymi i logistycznymi, w tym ograniczonym, a nawet całkowitym brakiem terenu budowy. Uwarunkowania te generują dodatkowe źródła ryzyka.

Niektóre z czynników ryzyka zostały przewidziane na etapie projektowania i podjęto odpowiednie kroki, aby zminimalizować ich skutki. Natomiast, w tego typu inwestycjach, większość źródeł ryzyka jest trudna do przewidzenia i występują one dopiero na etapie wykonywania robót budowlanych. Źródła tych ryzyk wynikają głównie z dwóch typów uwarunkowań, tj. utrudnień wynikających z umiejscowienia obiektu/ów na obszarze objętym programem rewitalizacji i w związku z tym koniecznością zachowania elementów substancji zabytkowej na tym terenie, oraz ograniczonego terenu budowy wynikającego z lokalizacji inwestycji w gęstej zabudowie miejskiej. 
Program Rewitalizacji Kwartału Świętego Wawrzyńca, przewidywał dla realizowanej inwestycji zachowanie wielu elementów zabytkowych. Zdecydowano zachować cały budynek administracyjny oraz przylegającą do niego ścianę frontową byłej hali turbin B2 od ulicy Wawrzyńca (Rys. 1). Wykonano ręczną rozbiórkę ścian murowych budynków elektrowni, aby po oczyszczeniu i przygotowaniu cegieł, użyć je ponownie w budowanych obiektach (Rys. 2). Podobnie wykorzystano część wyposażenia wnętrz elektrowni tj. część stolarki okiennej i drzwiowej, kamienną płycinę, stalową balustradę oraz pamiątkową tablicę producenta.

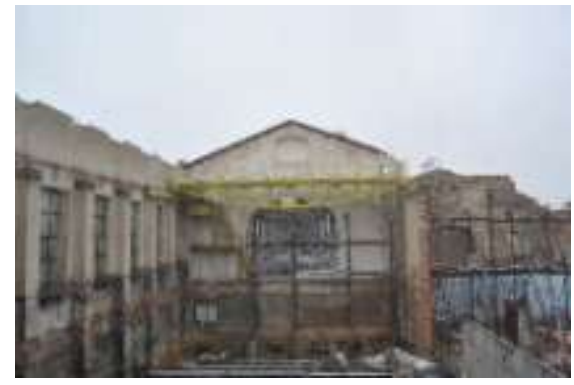

Rys. 1 Obiekt po częściowej rozbiórce, widok pozostawionych fragmentów starej

elektrowni, 12.10.2015, archiwum własne

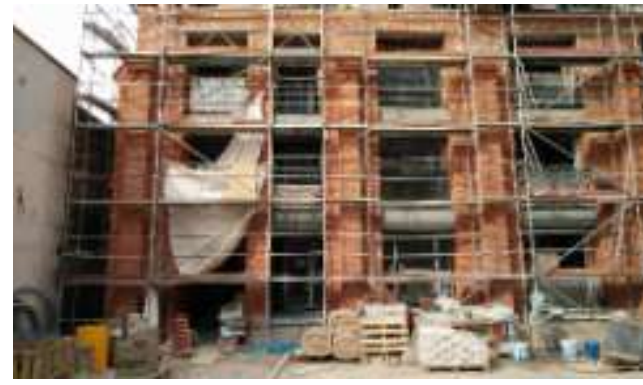

Rys. 2 Wbudowana zabytkowa cegła w nowopowstającą konstrukcję 21.03.2017, archiwum własne

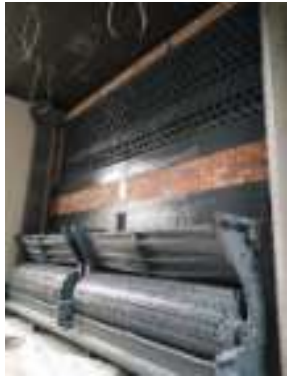

Rys. 3 Dwa odrestaurowane kotty firmy Zieleniewski 28.06.2016, archiwum własne

Urządzenia przemysłowe elektrowni mają charakter zabytków techniki. W związku z tym zdecydowano zachować kilka urządzeń technicznych w nowych budynkach. Jest to przede wszystkim suwnica w budynku B2 (widoczna na Rys. 1Fig. 7), która stanowiła jedno z poważniejszych źródeł ryzyka oraz piece umiejscowione w przejściu na dziedziniec kompleksu apartamentów (Rys. 3).

Wiele źródeł ryzyka w przedsięwzięciu pojawia się z tytułu lokalizacji budowy w gęstej zabudowie miejskiej. W tym przypadku były to fundamenty do wyburzenia, trudne warunki hydrogeologiczne, w zasadzie brak miejsca na zorganizowanie zaplecza budowy (do dyspozycji jako plac budowy był tylko dziedziniec i teren zabudowy kompleksu), utrudniony dostęp do wznoszonych konstrukcji i do dziedzińca oraz uciążliwy dojazd do miejsca budowy wąskimi przesmykami w otaczającej zabudowie.

Realizacja inwestycji budowlanych na terenach objętych rewitalizacją narażona jest na dodatkowe ryzyka, które nie występują w podczas realizacji nowych inwestycji, wśród nich można wymienić: wymagane dodatkowe projekty i pozwolenia wzmocnienia elementów konstrukcyjnych na czas realizacji przedsięwzięcia (np. wzmocnienie płyty przyszłego stropu pod posadowienie żurawia); nieprzewidziane koszty związane z koniecznością zachowania substancji zabytkowej lub konieczność zaplanowania nietypowych rozwiązań związanych z prowadzeniem sprawnej logistyki na placu budowy. Wiele ze źródeł ryzyka powtarza się w kolejnych przedsięwzięciach, dlatego też celowym jest zbieranie doświadczeń, gromadzenie wiedzy, uczenie się i wykorzystanie ich zarówno do zarządzania ryzykiem na poziomie operacyjnym, w odniesieniu do poszczególnego etapu, jak i strategicznym - do całego przedsięwzięcia.

Eliminacja źródeł ryzyka, zwłaszcza natury technicznej, wymaga od kierownictwa budowy dużych umiejętności i doświadczenia, starannego przygotowania robót budowlanych i zaprojektowania dodatkowych rozwiązań zapewniających bezpieczeństwo pracy. Uzyskane doświadczenia, ich analiza i ocena są podstawą do uogólnień i zaproponowania metodyki analizy i identyfikacji ryzyka w przedsięwzięciach obejmujących wykorzystanie istniejącej substancji budowlanej i zabytkowej. 